\title{
EFFECT OF ULTRA HIGH TEMPERATURE PROCESSING ON THE VISCOSITY OF WHOLE BOVINE MILK FORTIFIED WITH ZINC, FERROUS AND MAGNESIUM
}

\author{
Atallah Hameed Abdulghani \\ Department of Food Science \\ College of Agriculture \\ Tikrit University
}

\author{
Mahmood Younis Ali \\ Department of Food Science \\ College of Agriculture and Forestry \\ Mosul University
}

\begin{abstract}
Age gelation is a main defect in Ultra-high temperature (UHT) processed milk. It is a process with two stages which distinguished by loss of viscosity. It can be followed by measuring the apparent viscosity of the milk. A control $\left(\mathrm{T}_{0}\right)$ and four whole milk (fat 3.85\%) samples fortified with Zinc $\left(\mathrm{T}_{1}\right)$, Ferrous $\left(\mathrm{T}_{2}\right)$ and Magnesium $\left(\mathrm{T}_{3}\right)$ individually and collectively $\left(\mathrm{T}_{4}\right)$ was processed by indirect heating UHT system at $145^{\circ} \mathrm{C}$ for six seconds. The UHT-processed milk samples were filled aseptically into Gamma ray pre-sterilized PET containers in a laminar flow cabinet sterilized shortly before filling by UV. The samples stored at $30{ }^{\circ} \mathrm{C}$ for 60 days to investigate at 15 days intervals the effect of processing on apparent viscosity and appearance of the fortified milk and compared to control UHT milk $\left(\mathrm{T}_{0}\right)$. Results recorded during 60 days of storage showed a slight rise in viscosity in all samples. No changes in appearance have been observed during the storage period. UHT Zinc-milk has shown at all intervals insignificant increase. Only after 30 days of storage, milk-fortified with ferrous showed a significant increase in viscosity measured by spindle speed of $30 \mathrm{rpm}$ $\left(\mathrm{SS}_{30}\right)$. Significant increases $(\mathrm{p} \leq 0.05)$ in viscosity were recorded within the fortified UHT-milk samples. Appearance and apparent viscosity can be adopted to follow gel forming in fortified milk with some minerals.

Keywords: UHT milk, Viscosity, Fortification, Zn, Fe, Mg.
\end{abstract}

Received: 27/2/2013, Accepted: 6/5/2013.

\section{INTRODUCTION}

Age gelation in ultra high temperature (UHT) processed milk is a main defect distinguished by the formation of a soft curd and loss in fluidity (Manji et al., 1986). gelation is a two-stage process where proteolysis is followed by non-enzymatic physicochemical changes (Manji and Kakuda, 1988). It is formed by the aggregation of some micelles liberated from within casein micelles into the serum during heat processing to form a three-dimensional network (Harwalker, 1992, Venkatachalam et al., 1993). The aggregated network causes a gel formation when it reaches the critical concentration (McMahon, 1996). Datta and Deeth (2003) reported that the viscosity of fresh UHT milk was $3.0 \mathrm{mPa}$.s., and the most important factors which influence the onset of gelation include storage temperature and proteolysis during storage. On the other hand, Walstra et al. (2006) reported that the viscosity of the raw whole milk was $1.93 \mathrm{mPa}$.s. Swartzel et al. (1980) found the gelation of UHT milk samples to depend heavily on the fat percent. The lower the fat percent, the sooner the gelling started.

The research is a part of the Ph.D. thesis of the $1^{\text {st }}$ researcher. 
Kocak and Zadow (1985a) reported that the viscosity also depends on storage temperature; the viscosity of samples kept at $30^{\circ} \mathrm{C}$ increased during early storage stages, reaching a maximum of $8.5 \mathrm{mPa} . \mathrm{s}$ after 100 days of storage. McKellar et al. (1984) observed an increase in apparent viscosity and gel formation after 30 weeks in UHT milk processed by indirect heating. However, gelation is always preceded by a sharp rise in viscosity (Venkatachalam et al., 1993).

UHT milk viscosity develops during storage due to the activity of the native milk plasmin and some extracellular bacterial proteinases produced by psychrotrophic bacterial contaminants in the milk prior to heat processing which may survive the severe heat treatment of UHT processing (Touch and Deeth, 2009, Tondo et al., 2004). Although proteolytic activity is indirectly related to Age gelation (Kocak and Zadow, 1985a), but it leads to sensory, chemical and physical changes in UHT milk especially during storage period (Rajmohan et al., 2002, Schokker and van Boekel, 1999). These changes in stored milk lead in some cases to Age gelation which is also distinguished by increasing of viscosity rate. In addition, when the value exceeds $10 \mathrm{mPa}$.s, the UHT milk slowly is separated into "curds and whey" and then the viscosity sharply declines. A simple method to follow the development of Age gelation is to measure the apparent viscosity of the UHT milk (Nieuwenhuijse and van Boekel, 2003).

Objective of this research was to investigate the change in apparent viscosity and appearance of stored UHT milk samples fortified with Zn, Fe and Mgindividually and collectively during 60 days of storage at $30{ }^{\circ} \mathrm{C}$, and to examine the adequacy of viscosity measurement as reliable technique to predict Age gelling.

\section{MATERIALS AND METHODS}

Milk: Three different batches of homogenized and pasteurized whole bovine milk were collected from Parmalat (Queensland, Australia) during July, 2011. Average concentrations of the main components of the collected milk samples were shown in (Table 1).

Table (1): Average concentrations of some main components of the processed milk.

\begin{tabular}{|c|c|c|c|c|c|c|c|}
\hline Item & Fat & $\begin{array}{c}\text { Total } \\
\text { solids }\end{array}$ & $\begin{array}{c}\text { Solid } \\
\text { Non-Fat }\end{array}$ & $\begin{array}{c}\text { True } \\
\text { proteins }\end{array}$ & Caseins & $\begin{array}{c}\text { Whey } \\
\text { proteins }\end{array}$ & Lactose \\
\hline Mean* & 3.85 & 12.54 & 8.70 & 3.24 & 2.66 & 0.58 & 4.67 \\
\hline S.D. & 0.14 & 0.37 & 0.25 & 0.10 & 0.08 & 0.02 & 0.12 \\
\hline
\end{tabular}

* Average of 8 different samples of homogenized whole milk

Minerals: Sodium citrate (anhydrous) and sulphates of Zinc, Ferrous and Magnesium used were unopened containers and of analytical grade obtained from Sigma-Aldrich, Inc. (Australia). Depending upon Recommended Dietary Intake (RDI) for adults, approximate averages close to the fifty percent of RDI of the minerals have been used to prepare fortified milk samples (Table 2). In this work the RDI values of Zinc $\left(\mathrm{T}_{1}\right)$, Ferrous $\left(\mathrm{T}_{2}\right)$ and Magnesium $\left(\mathrm{T}_{3}\right)$ adopted were 16,8 and $320 \mathrm{mg} /$ day respectively. In 
UHT milk sample fortified collectively $\left(\mathrm{T}_{4}\right)$; the same amounts of minerals were added to one litre of whole milk. Magnesium samples were prepared taking in consideration the original amounts of magnesium in normal bovine milk $(\sim 120 \mathrm{mg} / \mathrm{l})$ (Walstra et al., 2006). Anhydrous sodium citrate was added to magnesium samples to prevent fouling caused by the coagulation of milk proteins due to high concentration of free magnesium.

Table (2): Minerals' concentrations used in preparing UHT-processed milk samples $(\mathrm{mg} / \mathrm{l})$.

\begin{tabular}{|c|c|c|c|c|c|c|}
\hline $\begin{array}{c}\text { Fortified milk with } \\
\text { minerals }\end{array}$ & $\begin{array}{c}\% 50 \text { of } \\
\text { RDI }\end{array}$ & $\begin{array}{c}\mathrm{ZnSO}_{4} \\
\mathrm{H}_{2} \mathrm{O}\end{array}$ & $\begin{array}{c}\mathrm{FeSO}_{4} \\
7 \mathrm{H}_{2} \mathrm{O}\end{array}$ & $\begin{array}{c}\mathrm{MgSO}_{4} \\
\text { Anhyd. }\end{array}$ & $\begin{array}{c}\mathrm{Na}_{3}\left(\mathrm{C}_{6} \mathrm{H}_{5} \mathrm{O}_{7}\right) \\
\text { Anhyd. }\end{array}$ \\
\hline Control & $\mathrm{T}_{0}$ & - & $/$ & $/$ & $/$ & $/$ \\
\hline Zinc & $\mathrm{T}_{1}$ & 8 & 21.94 & $/$ & $/$ & $/$ \\
\hline Ferrous & $\mathrm{T}_{2}$ & 4 & $/$ & 19.89 & $/$ & $/$ \\
\hline Magnesium* & $\mathrm{T}_{3}$ & 40 & $/$ & $/$ & 197.9 & 322.3 \\
\hline All minerals & $\mathrm{T}_{4}$ & $8,4,40$ & 21.94 & 19.89 & 197.9 & 322.3 \\
\hline
\end{tabular}
Original concentration of Mg was taken in consideration; only $40 \mathrm{mg} / \mathrm{l}$ was added to make a total of
160 mg/l ( \%50 RDI).

Fortification: Accurately weighted amounts of all salts were thoroughly dissolved in adequate amount of distilled water $(25 \mathrm{ml} /$ litre milk). Fortified whole milk samples were prepared by adding the dissolved salt into the milk and mixed gently shortly before heat treatment.

UHT Processing: UHT processing is conducted by a bench-top UHT plant at School of Agriculture \& Food Sciences (SAFS) in University of Queensland/ Australia, using indirect (tubular) heating system. The holding times in the preheating and hightemperature sections were $8 \mathrm{~s}$ at $95{ }^{\circ} \mathrm{C}$ and $6 \mathrm{~s}$ at $145^{\circ} \mathrm{C}$, respectively. After heat treatment, the milk samples were cooled to $\leq 35^{\circ} \mathrm{C}$ in $25 \mathrm{~s}$ in a tubular water-jacketed cooler. The flow rate was maintained at $150 \mathrm{ml} / \mathrm{min}$. The UHT-processed samples were filled aseptically into Gamma ray pre-sterilized Polyethylene terephthalate (PET) containers in a laminar flow cabinet sterilized by Ultra-violet light (UV) shortly before processing and filling. All samples were compared to neither treatment sample of UHT milk (control) plus $25 \mathrm{ml}$ of distilled water per each litre of milk and processed in the same manner.

Apparent Viscosity \& Appearance: The apparent viscosity (mPa.s) of the UHTprocessed milk-fortified with some minerals was measured by a Brookfield Viscometer (Model DV-II+ Viscometers, Brookfield Engineering Laboratories, INC., USA) fitted with a UL adaptor. The viscosity was measured at $20 \pm 1{ }^{\circ} \mathrm{C}$ using $16 \mathrm{ml}$ of the UHT milk sample. Spindle speeds of $30\left(\mathrm{SS}_{30}\right)$ and $60 \mathrm{rpm}\left(\mathrm{SS}_{60}\right)$ were used. The scale reading was taken after $30 \mathrm{sec}$, and viscosity was reported as a mean of three readings. At 15 days intervals, they were assessed for viscosity and any changes in the appearance of the milk such as clotting or curd formation in the lower portion of 
the container. The samples were stored for 60 days at $30{ }^{\circ} \mathrm{C}$. They were analyzed in triplicate and average results recorded.

Statistical Analysis: The complete randomized design (CRD) was used. Statistical differences were determined by using Duncan's multiple range test at $(\mathrm{P} \leq 0.05)$ using Statistical Analysis System (SAS) Version (2002).

\section{RESULTS AND DISCUSSION}

The effects of the UHT processing on the viscosity of whole milk samples fortified with some minerals were investigated. UHT fortified milk samples $\left(T_{1}, T_{2}, T_{3}\right.$ and $\left.\mathrm{T}_{4}\right)$ were compared to control UHT milk $\left(\mathrm{T}_{0}\right)$ in appearance and apparent viscosity.

Shortly after the processing, UHT milk samples showed neither clots nor any change in appearance. Viscosity values of fortified milk samples $\left(T_{1}, T_{2}, T_{3}\right.$ and $\left.T_{4}\right)$ measured by both spindle speeds at zero time (Table $3 \& 4$ ) were insignificantly close to that of control milk $\left(\mathrm{T}_{0}\right)$. However, the values were higher than that reported by Walstra et al. (2006) of raw whole milk. Most likely, this maybe is due to milk homogenization and other steps of the processing.

Table (3): The effect of UHT processing on the viscosity ( $m P a . s)$ of the whole milkfortified with some minerals measured by viscometer model DV-II+ fitted with UL adapter at $20{ }^{\circ} \mathrm{C}$, spindle speed of $30 \mathrm{rpm}\left(\mathrm{SS}_{30}\right)$ was used. $(\mathrm{Mean} \pm \mathrm{SD})^{*}$.

\begin{tabular}{|c|c|c|c|c|c|}
\hline \multirow{2}{*}{$\begin{array}{c}\text { Storage } \\
\text { life at 30 } \\
{ }^{\circ} \mathrm{C}(\text { days })\end{array}$} & \multirow{2}{*}{$\begin{array}{c}\text { Control } \\
\left(\mathrm{T}_{0}\right)\end{array}$} & $\begin{array}{c}\text { Zinc } \\
\left(\mathrm{T}_{1}\right)\end{array}$ & $\begin{array}{c}\text { Iron } \\
\left(\mathrm{T}_{2}\right)\end{array}$ & $\begin{array}{c}\text { Magnesium } \\
\left(\mathrm{T}_{3}\right)\end{array}$ & $\begin{array}{c}\text { All minerals } \\
\left(\mathrm{T}_{4}\right)\end{array}$ \\
\hline 0 & $2.160 \pm 0.21^{\mathrm{a}}$ & $2.160 \pm 0.21^{\mathrm{a}}$ & $2.160 \pm 0.21^{\mathrm{a}}$ & $2.220 \pm 0.05^{\mathrm{a}}$ & $2.233 \pm 0.12^{\mathrm{a}}$ \\
\hline 0 & $2.170 \pm 0.09^{\mathrm{b}}$ & $2.157 \pm 0.06^{\mathrm{b}}$ & $2.190 \pm 0.00^{\mathrm{b}}$ & $2.250 \pm 0.05^{\mathrm{b}}$ & $2.456 \pm 0.06^{\mathrm{a}}$ \\
\hline 35 & $2.193 \pm 0.06^{\mathrm{d}}$ & $2.207 \pm 0.06^{\mathrm{cd}}$ & $2.313 \pm 0.07^{\mathrm{c}}$ & $2.443 \pm 0.06^{\mathrm{b}}$ & $2.557 \pm 0.06^{\mathrm{a}}$ \\
\hline 45 & $2.233 \pm 0.06^{\mathrm{b}}$ & $2.233 \pm 0.06^{\mathrm{b}}$ & $2.323 \pm 0.06^{\mathrm{b}}$ & $2.523 \pm 0.06^{\mathrm{a}}$ & $2.623 \pm 0.06^{\mathrm{a}}$ \\
\hline 60 & $2.243 \pm 0.11^{\mathrm{b}}$ & $2.317 \pm 0.06^{\mathrm{b}}$ & $2.317 \pm 0.06^{\mathrm{b}}$ & $2.523 \pm 0.06^{\mathrm{a}}$ & $2.623 \pm 0.06^{\mathrm{a}}$ \\
\hline
\end{tabular}

$*$ Figures with different letters horizontally are significant $(\mathrm{p} \leq 0.05)$.

After 15 days of storage at $30^{\circ} \mathrm{C}$, all the values increased slightly. But only the viscosity of $\mathrm{T}_{4}$ tested by $\left(\mathrm{SS}_{30}\right)$ increased significantly $(\mathrm{p} \leq 0.05)$ without any change in appearance, meanwhile samples tested by $\left(\mathrm{SS}_{60}\right)$ showed higher values and were significant $(\mathrm{p} \leq 0.05)$ in comparison with $\mathrm{T}_{0}$.

Also, the tables $(3 \& 4)$ showed clearly that the heat treatment and storage (60 days $/ 30^{\circ} \mathrm{C}$ ) had no effect on $\mathrm{T}_{1}$ compared to $\mathrm{T}_{0}$; all values at all intervals, statistically were insignificant. Similarly, viscosity values of $\mathrm{T}_{2}$ showed the same behavior except after 30 days of storage which indicated a significant increase in viscosity $(p \leq 0.05)$. On the contrary, data of $\mathrm{T}_{3}$ and $\mathrm{T}_{4}$ showed significant differences in viscosity compared to $\mathrm{T}_{0}$. This unfavourable change may be attributed to the addition of sodium 
citrate (Table 2) which relatively increases the viscosity of UHT milks Kocak and Zadow (1985b).

Table (4): The effect of UHT processing on the viscosity ( $m P a . s)$ of the whole milkfortified with some minerals measured by viscometer model DV-II+ fitted with UL adapter at $20{ }^{\circ} \mathrm{C}$, spindle speed of $60 \mathrm{rpm}\left(\mathrm{SS}_{60}\right)$ was used. $(\mathrm{Mean} \pm \mathrm{SD})^{*}$.

\begin{tabular}{|c|c|c|c|c|c|}
\hline \multirow{2}{*}{$\begin{array}{c}\text { Storage } \\
\text { life at 30 } \\
{ }^{\circ} \mathrm{C} \text { (days) }\end{array}$} & $\begin{array}{c}\text { Control } \\
\left(\mathrm{T}_{0}\right)\end{array}$ & $\begin{array}{c}\text { Zinc } \\
\left(\mathrm{T}_{1}\right)\end{array}$ & $\begin{array}{c}\text { Iron } \\
\left(\mathrm{T}_{2}\right)\end{array}$ & $\begin{array}{c}\text { Magnesium } \\
\left(\mathrm{T}_{3}\right)\end{array}$ & $\begin{array}{c}\text { All minerals } \\
\left(\mathrm{T}_{4}\right)\end{array}$ \\
\hline 0 & $2.087 \pm 0.06^{\mathrm{a}}$ & $2.087 \pm 0.06^{\mathrm{a}}$ & $2.087 \pm 0.06^{\mathrm{a}}$ & $2.110 \pm 0.07^{\mathrm{a}}$ & $2.123 \pm 0.06^{\mathrm{a}}$ \\
\hline 15 & $2.050 \pm 0.00^{\mathrm{c}}$ & $2.086 \pm 0.06^{\mathrm{c}}$ & $2.123 \pm 0.06^{\mathrm{bc}}$ & $2.196 \pm 0.06^{\mathrm{b}}$ & $2.336 \pm 0.05^{\mathrm{a}}$ \\
\hline 30 & $2.123 \pm 0.06^{\mathrm{a}}$ & $2.133 \pm 0.06^{\mathrm{ab}}$ & $2.236 \pm 0.06^{\mathrm{ab}}$ & $2.270 \pm 0.10^{\mathrm{b}}$ & $2.450 \pm 0.07^{\mathrm{a}}$ \\
\hline 45 & $2.146 \pm 0.05^{\mathrm{cd}}$ & $2.140 \pm 0.06^{\mathrm{d}}$ & $2.246 \pm 0.08^{\mathrm{bc}}$ & $2.290 \pm 0.00^{\mathrm{b}}$ & $2.503 \pm 0.06^{\mathrm{a}}$ \\
\hline 60 & $2.160 \pm 0.00^{\mathrm{c}}$ & $2.193 \pm 0.06^{\mathrm{bc}}$ & $2.236 \pm 0.06^{\mathrm{bc}}$ & $2.283 \pm 0.05^{\mathrm{b}}$ & $2.520 \pm 0.06^{\mathrm{a}}$ \\
\hline
\end{tabular}

$*$ Figures with different letters horizontally are significant $(\mathrm{p} \leq 0.05)$.

In comparison with the findings of Datta and Deeth (2003), all recorded results of UHT milk samples were below $3.0 \mathrm{mPa}$.s. More than that, the viscosity values of stored samples were below the values observed $(2.75 \mathrm{mPa} . \mathrm{s})$ by Kocak and Zadow (1985a) during 60 days of storage at $30^{\circ} \mathrm{C}$. This may be attributed to the severe indirect heating process which destroys most of the existed proteinases. Some enzymes may survive the treatment, but they have no ability to affect the caseins potentially in 60 days. Also, UHT processing probably makes the casein micelles more resistant to alterations that promote accumulation through the storage period of UHT milk (Venkatachalam et al., 1993).

The changes in apparent viscosity of $\mathrm{T}_{0}, \mathrm{~T}_{1}$ and $\mathrm{T}_{3}$ were characterized by a long delay period in which only slight changes occurred during storage life. But, data of $\mathrm{T}_{3}$ and $\mathrm{T}_{4}$ showed higher levels of viscosity in both spindle speeds. These results were in agreement with the results found by Kocak and Zadow (1985b) in which they found that adding of sodium citrate to milk prior to UHT processing might increase the levels of the viscosity.

All stored milk samples showed no changes in appearance. And no clotting or gelling was recognized. Comparing viscosity values at zero time and the end of the storage life (Table 5), data of $\mathrm{T}_{0}$ and $\mathrm{T}_{1}$ measured by both spindle speeds increased insignificantly. In contrast, $\mathrm{T}_{3}$ and $\mathrm{T}_{4}$ showed significant rise in viscosity during 60 days of storage. On the other hand, it was observed that $\mathrm{T}_{2}$ behaved in different way, viscosity of stored milk tested by $\mathrm{SS}_{30}$ showed insignificant rise in contrast with that tested by $\mathrm{SS}_{60}(\mathrm{p} \leq 0.05)$.

UHT processing of milk-fortified with Zinc, Iron and Magnesium individually or collectively did not affect the viscosity of the milk. No clots in the lower portion of all milks' containers were observed during the 60 days of storage at $30^{\circ} \mathrm{C}$ and at 15 days 
intervals. Apparent viscosity can be adopted as a parameter to test Age gelation of fortified UHT-milk.

Table (5): The effect of storage for 60 days at $30^{\circ} \mathrm{C}$ on the viscosity of the whole milk-fortified with some minerals measured by viscometer model DV-II+ (mPa.s) fitted with UL adapter at $20^{\circ} \mathrm{C}$ (Mean \pm SD)*.

\begin{tabular}{|c|c|c|c|c|c|}
\hline \multicolumn{2}{|c|}{$\begin{array}{c}\text { Treatments } \\
\text { (UHT milk-fortified with,) }\end{array}$} & $\begin{array}{c}\text { Minerals, } \\
\text { added } \\
(\mathrm{mg} / \mathrm{l})\end{array}$ & $\begin{array}{l}\text { Spindle } \\
\text { speed }\end{array}$ & At zero time & $\begin{array}{l}\text { At the end of } \\
\text { storage life }\end{array}$ \\
\hline \multirow{2}{*}{ Control } & \multirow{2}{*}{$\mathrm{T}_{0}$} & \multirow[t]{2}{*}{ 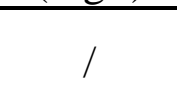 } & $\mathrm{SS}_{30}$ & $2.160 \pm 0.21^{\mathrm{a}}$ & $2.243 \pm 0.11^{\mathrm{a}}$ \\
\hline & & & $\mathrm{SS}_{60}$ & $2.087 \pm 0.06^{\mathrm{a}}$ & $2.160 \pm 0.00^{\mathrm{a}}$ \\
\hline \multirow{2}{*}{ Zinc } & \multirow{2}{*}{$\mathrm{T}_{1}$} & \multirow{2}{*}{8} & $\mathrm{SS}_{30}$ & $2.160 \pm 0.21^{\mathrm{a}}$ & $2.317 \pm 0.06^{\mathrm{a}}$ \\
\hline & & & $\mathrm{SS}_{60}$ & $2.087 \pm 0.06^{\mathrm{a}}$ & $2.193 \pm 0.06^{\mathrm{a}}$ \\
\hline \multirow{2}{*}{ Ferrous } & \multirow{2}{*}{$\mathrm{T}_{2}$} & \multirow{2}{*}{4} & $\mathrm{SS}_{30}$ & $2.160 \pm 0.21^{\mathrm{a}}$ & $2.317 \pm 0.06^{\mathrm{a}}$ \\
\hline & & & $\mathrm{SS}_{60}$ & $2.087 \pm 0.06^{\mathrm{a}}$ & $2.237 \pm 0.06^{b}$ \\
\hline \multirow{2}{*}{ Magnesium } & \multirow{2}{*}{$\mathrm{T}_{3}$} & \multirow{2}{*}{40} & $\mathrm{SS}_{30}$ & $2.220 \pm 0.05^{\mathrm{a}}$ & $2.523 \pm 0.06^{b}$ \\
\hline & & & $\mathrm{SS}_{60}$ & $2.110 \pm 0.07^{\mathrm{a}}$ & $2.283 \pm 0.05^{b}$ \\
\hline \multirow{2}{*}{ All minerals } & \multirow{2}{*}{$\mathrm{T}_{4}$} & \multirow{2}{*}{$8,4,40$} & $\mathrm{SS}_{30}$ & $2.233 \pm 0.12^{\mathrm{a}}$ & $2.623 \pm 0.06^{b}$ \\
\hline & & & $\mathrm{SS}_{60}$ & $2.123 \pm 0.06^{\mathrm{a}}$ & $2.523 \pm 0.06^{b}$ \\
\hline
\end{tabular}

* Figures with different letters horizontally are significant $(\mathrm{p} \leq 0.05)$.

ACKNOWLEDGEMENT: The authors extend sincere appreciation to Professor Hilton Deeth for his full support and are grateful to Honest Madziva and Shiou Pang for assistance with the practical lab work.

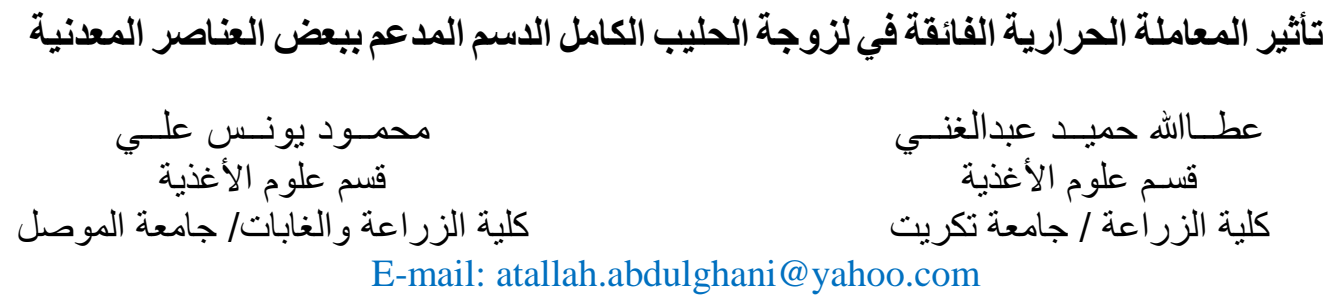

E-mail: atallah.abdulghani@yahoo.com

\section{الخلاصة}

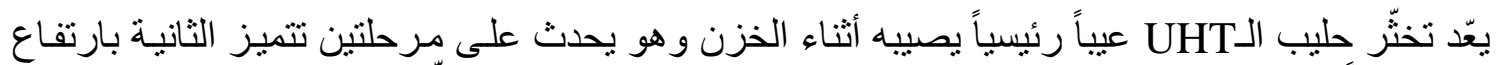

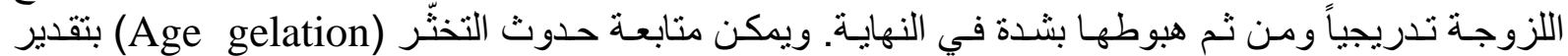

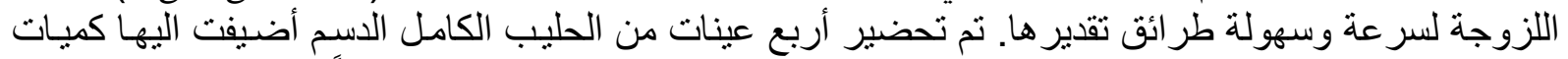

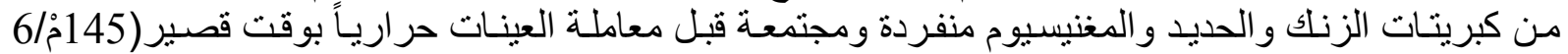

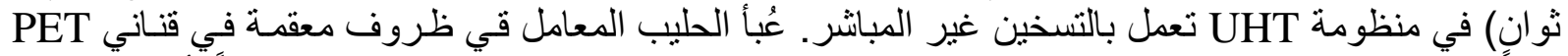

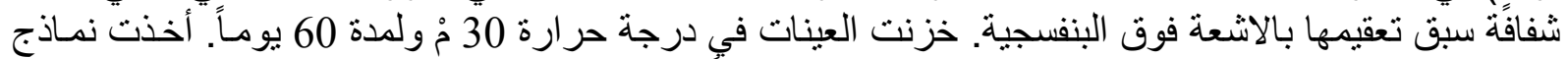

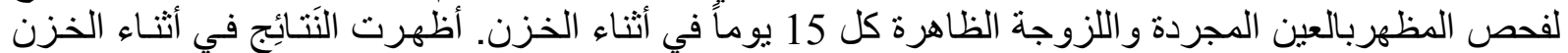

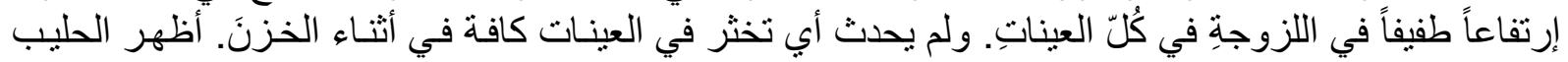

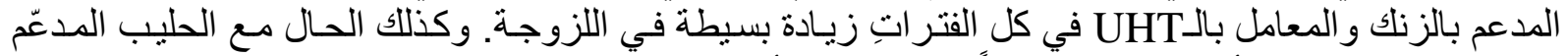

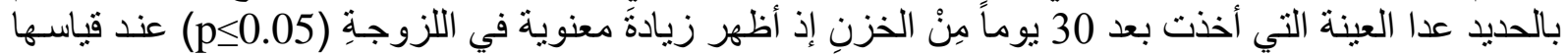

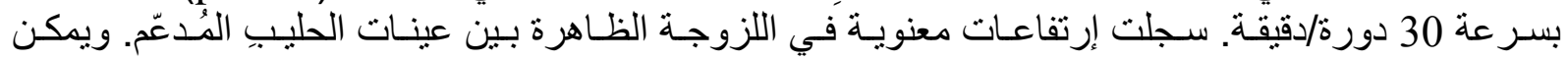




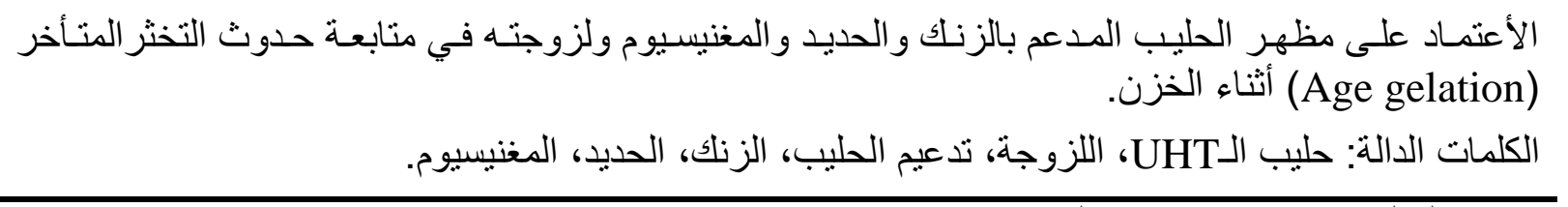

تاريخ تسلم البحث: 2013/2/27 ،وقبوله: 2013/5/6.

\section{REFERENCES}

Anonymous (2002). Statistical Analysis systems. Software, v. 9, SAS Institute, Cary, $\mathrm{NC}$.

Datta, N. and H. Deeth (2003). Diagnosing the cause of proteolysis in UHT milk. Lebensmittel-Wissenschaft und-Technologie 36(2):173-182 (Abstract).

Harwalkar, V. (1992). Age gelation of sterilized milks. In: Advanced Dairy Chemistry, Volume (1A): Proteins pp. 691-734. Elsevier Science Publishers Ltd, London.

Kocak, H. and J. Zadow (1985a). Age gelation of UHT whole milk as influenced by storage temperature. Australian Journal of Dairy Technology 40(1):14-18.

Kocak, H. and J. Zadow (1985b). Controlling age gelation of UHT milk with additives. Australian Journal of Dairy Technology 40(2):58-64.

Manji, B. and Y. Kakuda (1988). The role of protein denaturation, extent of proteolysis, and storage temperature on the mechanism of age gelation in a model system. Journal of Dairy Science 71(6): 1455-1463.

Manji, B.; Y. Kakuda and D. Arnott (1986). Effect of storage temperature on age gelation of ultra-high temperature milk processed by direct and indirect heating systems. Journal of Dairy Science 69(12):2994-3001.

McKellar, R.; D. Froehlich; G. Butler; H. Cholette and C. Campbell (1984). The effect of uncooled storage on proteolysis bitterness and apparent viscosity in ultrahigh-temperature milk. Journal of the Canadian Institute of Food Science and Technology 17(1): 14-17. (Abstract).

McMahon, D. (1996). Age-gelation of UHT milk: Changes that occur during storage, their effect on shelf life and the mechanism by which age-gelation occurs. In: Proceedings of the IDF: Heat Treatments and Alternative Methods. Special Issue, Document 9602, pp. 315-325, International Dairy Federation. Brussels. (Abstract).

Nieuwenhuijse, J. and M. van Boekel (2003). Protein Stability in Sterilised Milk and Milk Products. In: Advanced Dairy Chemistry: Proteins. Edited by P. Fox, and P. McSweeney. pp. 947-974. Kluwer Academic/Plenum Publishers. New York.

Rajmohan, S.; C. Dodd and W. Waites (2002). Enzymes from isolates of Pseudomonas fluorescens involved in food spoilage. Journal of Applied Microbiology 93(2):205-213.

Schokker, E. and M. van Boekel (1999). Kinetics of thermal inactivation of the extracellular proteinase from Pseudomonas fluorescens 22f: influence of $\mathrm{pH}$, calcium, and protein. Journal of Agricultural and Food Chemistry 47(4):16811686. 
Swartzel, K.; D. Hamann and A. Hansen (1980). Rheological modeling of UHT milk gels using a cone and plate creep-relaxation test. Journal of Food Process Engineering 3(3):161-174.

Tondo, E.; F. Lakus; F. Oliveira and A. Brandelli (2004). Identification of heat stable protease of Klebsiella oxytoca isolated from raw milk. Letters in Applied Microbiology 38(2):146-150.

Touch, V. and H. Deeth (2009). Microbiology of raw and market milks. In: Milk Processing and Quality Management. Edited by A. Tamime. pp. 48-71. WileyBlackwell.

Venkatachalam, N.; D. McMahon and P. Savello (1993). Role of protein and lactose interactions in the Age gelation of ultra-high temperature processed concentrated skim milk. Journal of Dairy Science 76(7): 1882-1894.

Walstra, P.; J. Wouters and T. Geurts (2006). Dairy Science and Technology. Chapter (2), Milk components. pp. 17-108. CRC Press, Taylor and Francis Group, Boca Raton, Florida. 